\title{
Dermatologic Emergencies
}

\author{
Dermatolojik Aciller
}

Selami Aykut Temiz,

Ilkay Ozer ${ }^{1}$,

Arzu Ataseven ${ }^{1}$

1 Necmettin Erbakan University, Meram Faculty of Medicine, Department of Dermatology

Geliş Tarihi/Received: 1 July 2018 Kabul Tarihi/Accepted: 2 January 2019

Address correspondence to: Selami Aykut Temiz, Necmettin Erbakan University, Meram Faculty of Medicine, Department of Dermatology, Konya, Turkey e-mail: aykutmd42@gmail.com

\section{ORCID}

Selami Aykut Temiz

https://orcid.org/0000-0003-4878-0045 Ilkay Ozer

https://orcid.org/0000-0001-6170-0930

Arzu Ataseven

https://orcid.org/0000-0001-5372-0712

\begin{abstract}
Öz
Acil tıbbi durumlar, hızlı karar vermeyi ve bu kararları mortalite ve morbiditeyi önlemek için hızla uygulamayı gerektirir. Dermatolojik acil durumlar, öncelikle primer deri kaynaklı hastalıklar veya altta yatan sistemik hastalıklar ve enfeksiyonlar ile ilişkili hastalıklar olarak ortaya çıkabilir. Dermatolojik acil durumlar, diğer tıp dallarından daha nadir olmakla birlikte, yaşamı tehdit eden, yüksek mortalite oranına sahip, yaşam kalitesini olumsuz yönde etkileyen ve büyük oranda hastaneye yatıs ya da yoğun bakım ünitesine yatışa intiyaç duyan, olası bir tıbbi tedaviyi hemen vermeyi gerektiren vakaları içermektedir. Ürtiker-anjiyoödem, stevens-johnson sendromu, toksik epidermal nekroliz, toksik şok sendromu, eritrodermi, gebeliğin pruritik ürtikeryal papül ve plakları, otoimmün büllöz hastalıklar, akut graft versus host hastalığı, haşlanmıs deri sendromu ve nekrotizan sellülit gibi mortalite ve morbiditeye neden olan hastalıklar dermatolojik acil durumlar olarak bilinir. Dermatolojik acil durumları saptamak; acil tıbbi müdahale sağlamak, mortalite ve morbidite insidansını azaltmak ve dermatolojik acil olmayan durumlarda da gereksiz konsültasyon, tedavi, para ve zaman kaybını önlemek için önemlidir. Dermatolojik acil durumları, etiyopatogenez, klinik, ayırıcı tanı ve tedavi başlıkları altında inceledik, dermatoloji ve dermatoloji dışı hekimlere pratik yaklaşımları derledik.

Anahtar Kelimeler: Dermatolojik aciller, dermatoloji konsultasyon, acil tıp

\section{Abstract}

Emergency medical conditions involve rapid decision making and applying these decisions to prevent mortality and morbidity. Dermatologic emergencies may primarily occur in association with skin-involved diseases, and underlying systemic diseases or infections, as well. Dermatologic emergencies are uncommon than other branches of medicine; however, it involves the cases of potentially life-threatening, having high mortality rate, negatively effecting the quality of life on highest degrees, and requiring hospitalization or intensive care units, if possible, to give a convenient medical treatment immediately. The diseases causing mortality and morbidity, such as Urticaria-angioedema, Stevens-Johnson syndrome, toxic epidermal necrolysis, toxic shock syndrome, erythroderma, pruritic urticarial papules and plaques of pregnancy (PUPPP), autoimmune bullous diseases, acute graft versus host disease, scalded skin syndrome and necrotizing cellulitis, are known as dermatologic emergencies. Determining the dermatologic emergencies and providing an immediate medical response decreases the incidence of mortality and morbidity, and they are important to prevent unnecessary examinations, treatment, money and time loss for the consultation of conditions even they are not real dermatologic emergencies. We examined the dermatologic emergencies under the titles of etiopathogenesis, clinics, differential diagnosis and treatment, and we edited practical approaches for dermatology and non-dermatology physicians.
\end{abstract}

Key words: Dermatologic emergencies, dermatology consultation, emergency medicine

\section{INTRODUCTION}

In dermatology, emergencies are more uncommon than in other branches of medicine; however, emergencies that have a high mortality rate, that negatively affect quality of life, and that requiring hospitalization and even stays in intensive care units do occur (1). In these cases, it is important to give medical treatment immediately $(1,2)$. In various studies in the literature, it has been reported that
5 to $8 \%$ of the complaints of patients admitted to emergency rooms were related to skin problems (3). Erdogan et al. (4) reported that the most frequent reasons for consultations requested from the emergency service were urticaria-angioedema $(30.25 \%)$, contact dermatitis $(11.5 \%)$, and insect bite $(9.75 \%)$. In the same study, the most common diseases in pediatric patients were reported as insect bite $(31.17 \%)$, acute urticaria-angioedema
Cite this article as: Temiz SA, Ozer I, Ataseven A. Dermatologic Emergencies Selcuk Med J 2020;36(2): 157-167
Disclosure: None of the authors has a financial interest in any of the products, devices, or drugs mentioned in this article. The research was not sponsored by an outside organization. All authors have agreed to allow full access to the primary data and to allow the journal to review the data if requested. 
(28.57\%), and contact dermatitis (9\%). In the study by Bancalari-Díaz et al. (5) that evaluated dermatologic emergencies, the most common most disease was urticaria-angioedema $(7.6 \%)$, followed by contact dermatitis $(6.1 \%)$, and drug reactions (4.6\%). In our country, the ratio of dermatologic consultations requested for insect bite is relatively high although insect bite is not a dermatologic emergency condition within the normal definition of an emergency (4).

We examined dermatologic emergencies under the topics of etiopathogenesis, clinics, differential diagnosis, and treatment, and we listed practical approaches for dermatologists and non-dermatologist physicians.

\section{URTICARIA-ANGIOEDEMA}

Urticaria is characterized by pruritic, erythematous plaques that blanch without scarring within 24 hours (6). Urticaria is considered as acute if it lasts less than 6 weeks. Urticaria is commonly accompanied by angioneurotic edema (AE); however, both clinical conditions might arise separately. Since AE occurs in deeper layers of the skin that have fewer mast cells and sensory nerves, pruritus is less common than urticarial lesions. It is usually defined as "painful" by patients. There is no redness or increase of heat in the swollen areas. In addition to the skin, oral mucosa and gastrointestinal mucosa might be also affected. The first indication of respiratory tract involvement might be a speech disorder.

Symptoms, such as uvula edema and teeth marks on the tongue, should be investigated in patients who are admitted to the emergency service with urticaria. Since the presence of uvula edema or larynx involvement (larynx edema) might cause respiratory distress and have a life-threating effect, patients should be hospitalized, and treatment should be initiated immediately (6). The boundaries of the lesion are not definite in angioedema in comparison to urticaria, and lesions usually disappear within 72 hours (6).

\section{Differential Diagnosis}

The diagnosis of urticaria can be easily confirmed with anamnesis and physical examination. Especially in cases with a history of longer than 24 hours, it is important to discriminate urticaria from urticarial vasculitis. Urticarial vasculitis is characterized by purpura, long lasting lesions that persist for more than a day, and hyperpigmentation. Other possible causes of swelling in the $\mathrm{AE}$ region should be considered in differential diagnosis, as well. The presence of local inflammatory diseases, such as cellulitis, edema secondary to operation, and dental abscess should be eliminated. Routine laboratory tests are not recommended in patients with acute urticaria (7). If there is an allergic trigger in the patient's history, a skin prick test can be performed; however, it is not recommended in clinical practice due to the risk of triggering reactions (7).

Angioedema occurs alone in 11 to $20 \%$ of the cases; in these cases, hereditary C1 esterase inhibitor deficiency should be considered in a differential diagnosis (8). Of the cases with hereditary angioedema, $80 \%$ have a family history, and it has an autosomal dominant pattern. If hereditary angioedema (HEA) is considered, the C4 plasma concentration should be measured, and the $\mathrm{C} 1$ inhibitor level should be requested in cases of low $\mathrm{C} 4$ concentration (8). The differences in angioedema attacks from isolated angioedema is the absence of urticarial plaques and non-response to adrenaline, steroid, and antihistaminic therapy. The main treatment for acute HEA is the C1-inh concentrate. C1-inh concentrate is recommended as a $1000 \mathrm{U}$ IV. In the absence of C1 esterase inhibitor solution, fresh frozen plasma infusion is life-saving. The recommended dose is the administration of 1-2 units of fresh frozen plasma within 1-2 hours (8).

\section{Treatment}

Emergency patients with angioedema should be immediately put under supervision, and the following treatment protocol should be applied (Table 1). The first step in the treatment of acute and chronic urticaria involves second generation antihistamines that have minimum sedative and cholinergic effects.

Table 1. Emergency treatment protocol

1. Adrenalin: intramuscular or subcutaneous dose is 0.3 to $0.5 \mathrm{ml}$ of adrenaline $1 / 1000$ (1 $\mathrm{mg} / \mathrm{ml}) \mathrm{in}$ adults, repeat every 5 to 20 minutes, if necessary, the maximum dose is $0.5 \mathrm{mg}$.

2. Hydration should be assured via vascular access

3. Oxygen should be administered (5-10 L/min)

4. Systemic corticosteroids ( $1 \mathrm{~g} / \mathrm{kg}$ of IV prednisolone)

5. Systemic antihistamines (IV diphenhydramine or pheniramine maleate) 
A single dose is usually administered, and the dose can be increased to 4 times per day. Regular daily use is recommended even there are no symptoms every day, and the treatment should be continued for at least 4 to 6 weeks $(7,8,9)$.

The pregnancy category for loratadine and cetirizine is $\mathrm{B}$. They can be used during pregnancy and lactation; however, antihistamines are not recommended in the third trimester of the pregnancy due to the risk of early membrane rupture (9). Shortterm systemic corticosteroids can be used in all urticaria cases; the initial dose of prednisolone is 0.5 to $1 \mathrm{mg} / \mathrm{kg} /$ day and then discontinued within 5 to 7 days by gradually reducing the dose (9).

\section{ANAPHYLAXIS}

Anaphylaxis is a life-threatening and a systemic Type-1 hypersensitivity reaction associated with $\lg$ E that might develop because of the influence of mediators secreted from mast cells and basophiles (10). The most common causes of IgE-mediated anaphylaxis are insect sting (especially bee) or exposure to drugs, latex, peanuts, hazel trees, shellfish, fish, milk, eggs, or wheat. Exercise, aspirin, non-steroidal anti-inflammatory drugs, opiates, and radiocontrast substances might also lead to anaphylaxis; however, anaphylactic reactions triggered by these agents are developed as a result of non-lgE mediated mechanisms $(10,11)$. Non-immunological mechanisms might also cause anaphylaxis (10).

In addition to the skin symptoms, the clinical symptoms of anaphylaxis might be observed in the gastrointestinal system, the respiratory system, and the cardiovascular system (11). The most common clinical symptoms involve urticaria, angioedema, erythema, and pruritus; and cardiopulmonary arrest develop in association with respiratory distress and cardiovascular collapse (11). Skin symptoms may be absent in $20 \%$ of the cases, and this condition complicates the diagnosis (10).

\section{Differential Diagnosis}

The presence of one of the following three options is sufficient for the diagnosis of anaphylaxis (11).

1) Acute onset of skin or mucosal involvement, urticaria, pruritus, redness, or angioedema, and at least one of the following:

a. Difficulty in breathing; wheezing, stridor

b. Organ dysfunction or decrease in blood pressure

2) At least two findings following acute exposure to allergen-like substances a. Skin or mucosal involvement (urticaria, redness, edema)

b. Difficulty in breathing; wheezing, stridor

c. Organ dysfunction or decrease in blood pressure vomiting)

d. Recurrent gastric complaints (nausea,

3) Decrease in blood pressure after exposure to a known allergen.

Urticaria, angioedema, mastocytosis, hereditary angioedema, arrhythmia, acute coronary syndrome, poisoning, hyperglycemia, carcinoid syndrome, and panic attack are diseases involved in a differential diagnosis (11).

\section{Treatment}

The potential causes of anaphylaxis should be initially eliminated. Adrenaline and oxygen therapy are the most significant agents. The IM dose of adrenaline is $1 / 1000$ per $0.01 \mathrm{mg} / \mathrm{kg}$ of body weight up to a maximum of $0.5 \mathrm{mg}(10)$. It may be repeated every 5 to 20 minutes unless a clinical recovery is observed.

IV hydration therapy of $1000 \mathrm{ml}$ is given to adults, and a crystalloid bolus of $20 \mathrm{ml} / \mathrm{kg}$ is given to children. Inhaled beta-2 agonists, antihistamines (H1antagonist diphenhydramine IM or slow IV infusion), glucocorticosteroids (prednisolone $1 \mathrm{mg} / \mathrm{kg}$ IV), and vasopressors can be used for bronchospasm, larynx edema, and hypotension, respectively according to treatment priority in anaphylaxis (Table 2). Following clinical recovery, the recurrence of the symptoms within 1 to 72 hours is called a biphasic reaction (10).

\section{STEVEN-JOHNSON SYNDROME AND TOXIC EPIDERMAL NECROLYSIS}

Steven-Johnson syndrome (SJS) and toxic epidermal necrolysis (TEN) are delayed-type hypersensitivity reactions to drugs that typically involves the skin and the mucous membranes and are accompanied by severe mortality and morbidity (12). They usually occur 1 to 45 days after the

Table 2. Acording to treatment priority in anaphylaxis
1. IM Adrenalin
2. Oxygen therapy
3. Patient positioning
4. IV hydration therapy
5. Nebulizer therapy
6. Vasopressors
7. Antihistamines
8. Corticosteroids 


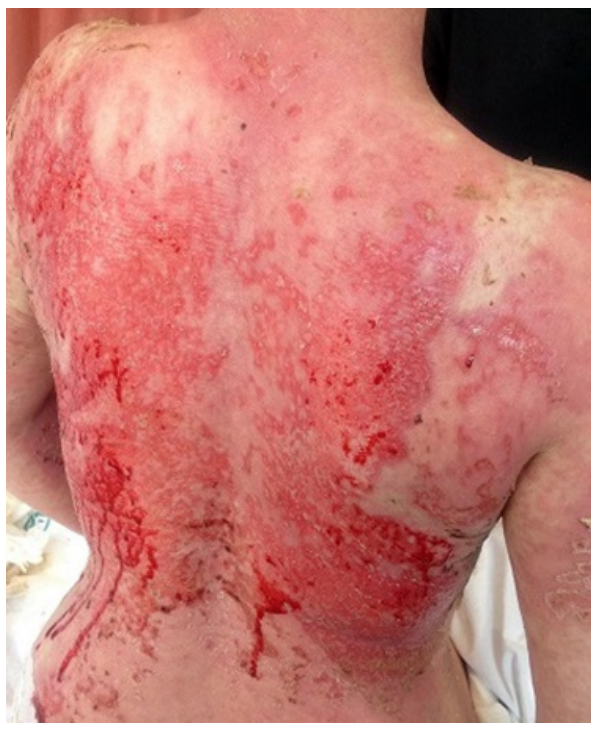

Figure 1. Widespread epidermal decomposition in toxic epidermal necrolysis (TEN)

initiation of drug therapy (14 days on average). An etiological agent (idiopathic) is not detected in $5 \%$ of the cases (12). These conditions are characterized by Nikolsky-positive bullous and target-like lesions associated with epidermal separation (Figure 1) and mucosal involvement on the erythematous base (12). If epidermal separation involves $10 \%$ of the body surface area, it is called SJS; the involvement of 10 to $30 \%$ of the body surface area is considered a SJS/TEN overlap; and if it affects more than $30 \%$ of the body surface, it is called TEN (13). In addition, the involvement of at least two mucosal surfaces, involving oral, genital, or ocular mucosa, is required (13).
Prodromal indications involve fever, conjunctivitis, pharyngitis, and pruritus, and it may persist for 2 to 3 days. Following the symptoms of a conjunctival burning sensation, skin sensitivity, local erythema, fever, and arthralgia, the outbreak covers the whole body by initiating as morbilliform eruptions with targetlike lesions, and vesicles appear on the erythematous areas, evolves to large and flaccid bullous, and leaves red eroded areas (12).

\section{Differential Diagnosis}

The clinical symptoms are usually adequate for the diagnosis; however, obtaining a skin biopsy is recommended for a differential diagnosis (14). Mucosal involvement, in particular, should be an indicator for SJS/TEN (14). It might be diagnosed as staphylococcal scalded skin syndrome (SSSS), linear IgA bullous dermatosis, acute generalized exanthematous pustulosis (AGEP), or generalized bullous fixed drug reactions; thus, a biopsy is necessary for a differential diagnosis (15). A histopathological examination reveals necrosis involving all layers of epidermis, and necrotic keratinocytes are observed (16).

\section{Treatment}

The most important step in treatment is early diagnosis and cessation of the drug. Patient should be followed up in burn or intensive care units; there is a correlation between follow-up in a burn unit and overall survival (17). The SCORTEN scale (Table 3) was developed to assess TEN, which is widely used to predict the severity of the disease and the mortality rate accordingly. It is extremely important that patients with a SCORTEN score 3 (mortality rate: $35.3 \%$ ) or higher are transferred quickly to the burn unit or intensive care unit (16). Patients should be evaluated in terms of respiratory system, renal functions, fluid-

Table 3. SCORTEN score and accompanying mortality rates

\begin{tabular}{|c|c|c|c|}
\hline Parameters & Individual Points & $\begin{array}{l}\text { SCORTEN Score } \\
\text { (sum of individual } \\
\text { points) }\end{array}$ & $\begin{array}{l}\text { Mortality Rate } \\
(\%)\end{array}$ \\
\hline Age $\geq 40$ years & 1 & $0-1$ & 3.2 \\
\hline Presence of malignancy & 1 & 2 & 12.1 \\
\hline $\mathrm{BUN}>28 \mathrm{mg} / \mathrm{dl}(>10 \mathrm{mmol} / \mathrm{L})$ & 1 & 3 & 35.3 \\
\hline \multicolumn{4}{|l|}{ Serum Glucose > 252 mg/dl } \\
\hline$(>14 \mathrm{mmol} / \mathrm{L})$ & 1 & 4 & 58.3 \\
\hline Heart rate $\geq 120$ per minute & 1 & $\geq 5$ & 90 \\
\hline Serum Bicarbonate $<20 \mathrm{mmol} / \mathrm{L}$ & 1 & & \\
\hline Body surface epidermal detachment $>10 \%$ & 1 & & \\
\hline
\end{tabular}


Table 4. Supplement therapy is summarized in nine steps for TEN

1. Detection of patency of the airway

2. Infection control; blood, urine and skin cultures should be taken in patients with infection and highest risk of developing sepsis; routine antibiotic prophylaxis is not recommended.

3. Maintenance of skin and mucosal lesions; stable bullae should be aspirated with an injector; bullae wall should not be removed. Mucosal areas should be followed in the early period to avoid adhesions and strictures in the mucosal area and ophthalmic consultation for ocular lesions and gynecology or urology consultations for genital lesions should be performed.

4. Thermoregulation; it is recommended to keep the room temperature at 28 to $32{ }^{\circ} \mathrm{C}$, beds with heater should be used (if necessary).

5. Maintenance of fluid-electrolyte balance; fluid-electrolyte therapy is recommended as; electrolyte solutions $(0.7 \mathrm{ml} /$ $\mathrm{kg} /$ body surface area $\%$ ) and albumin solution ( $5 \%$ albumin, $1 \mathrm{ml} / \mathrm{kg} /$ affected area $\%$ ).

6. Diet; protein-rich and high calorie diets is recommended to the patients.

7. Pain control; mattresses and analgesics preventing decubitus ulcer is recommended to the patients.

8. Venous thromboembolism prophylaxis; routine anticoagulant prophylaxis is recommended.

9. Psychological support; psychological support should be provided to the patients and his/her relatives.

electrolyte balance, infections, eye lesions, and pain control (17). Supplemental therapy is summarized in nine steps for TEN (Table 4).

There is no standard therapy for TEN (16). Several immunosuppressive or immunomodulatory therapy models has been created using systemic corticosteroids, intravenous immunoglobulin (IVIG), cyclosporine, and plasmapheresis and tumor necrosis factor alpha inhibitors; however, the data associated with these therapies are limited and contradictive (1618). Mortality might occur within 6 weeks after the onset of disease, and it is typically associated with disease complications (14). The most common cause of mortality is transepidermal fluid loss, sepsis-related multi-organ failure, shock. Pulmonary embolism, acute respiratory distress syndrome (ARDS), cardiac dysfunction, gastrointestinal bleeding and renal failure are among the other causes of mortality (14).

\section{STAPHYLOCOCCAL SCALDED SKIN SYNDROME}

Staphylococcal scalded skin syndrome (SSSS), also known as Ritter's syndrome, is an exfoliative dermatitis in newborns and children under 5 years of age that results from injection of exfoliative-toxinproducing staphylococcus aureus. The mortality rate in adults may reach $60 \%$ due to comorbidities (19). Staphylococcus aureus (S. aureus) phage group II (Type 3A, 3B, 5S, 71) is generally responsible for SSSS (20).

\section{Differential Diagnosis}

SSSS is usually clinically diagnosed; however, skin biopsy is the accurate diagnostic method. TEN, SJS, toxic shock syndrome, Kawasaki disease, epidermolysis bullosa, and bullous impetigo should be considered for a differential diagnosis in patients suspected of SSSS (21). Although systemic glucocorticosteroids are preferred for drug eruptions involving TEN, they are contraindicative in SSSS (21). Therefore, a differential diagnosis is very important. While Nikolsky positive erythematous bullous are also present in TEN, it is accompanied by mucosal lesions; the absence of mucosal lesions in SSSS may assist in the diagnosis (21). Moreover, a histopathological examination of TEN reveals dermoepidermal separation and necrosis of the whole epidermis. Lesions are clinically seen in the flexural regions such as the axillary and groin areas. SSSS is induced by Group 2 staphylococcus epidermolytic exotoxin $A$ and $B$. These two toxins cause a loss of intercellular connection, epidermal separation, and infection by targeting desmoglein-1 that provides the intercellular connection for the keratocytes (22).

\section{Treatment}

Anti-staphylococcal anti-biotherapy should be initiated immediately for treatment of toxin-dependent disease (22). S. aureus is resistant to penicillinase since it produces beta-lactamase; thus, parenteral beta-lactamase resistant penicillin should be given to patients, and vancomycin is recommended for patients resistant to methicillin (22). It is also important to maintain the fluid-electrolyte balance of the patients. In the literature, patients showed improvement in response to IV immunoglobulin treatment $(0.4-1 \mathrm{~g} / \mathrm{kg} /$ day for 5 days) $(22,23)$.

Mortality is usually associated with late-diagnosis, failure to begin proper antibiotic therapy, secondary 
infections, pneumonia, fluid-electrolyte imbalance, and sepsis.

\section{TOXIC SHOCK SYNDROME}

Toxic shock syndrome (TSS) is characterized by fever, skin rash, hypotension, and multiorgan involvement (24). The toxins secreted from certain strains of S. aureus and S. pyogenes act a superantigen effect and lead to shock by causing intense activation of T-lymphocytes and secretion of proinflammatory cytokines. S. aureus secretes 5 different enterotoxins (A, B, C, D, E) and TSStoxin1. The strains of $S$. pyogenes are $M$ type 1,3 and streptococcal-pyrogenic exotoxin A. The use of tampons or aggravated mucosal ulcerations are the access paths for S. aureus (25). The incidence of streptococcal TSS is reported to be higher in recent epidemiological studies (25). The mortality rate for streptococcal TSS is higher in recent studies (26). Streptococcal TSS is diagnosed by the presence of a generalized erythematous eruption, fever, mucosal membrane involvement, hypotension, and functional disorders in at least three organs (the gastrointestinal system; the muscles; the mucosal membrane; the kidneys; and the hepatic, hematological, and central nervous system) (25).

\section{Differential Diagnosis}

Septic shock, staphylococcal scalded skin syndrome, Kawasaki disease, measles, meningococcal meningitis, leptospirosis, or SJS/ TEN syndrome may be considered for differential diagnosis (27). The cultu re of the infected area is usually positive. Staphylococcus is isolated in $90 \%$ of the vaginal cultu res of cases with menstrual TSS (26).

\section{Treatment}

First, foreign bodies should be eliminated, and then penicillinase-resistant anti-staphylococcal antibiotic therapy is initiated. Thus, $\beta$-lactam and lincosamides, such as clindamycin, are the first-line drugs (26). It is known that early and adequate antibiotic therapy decreases the mortality rate (27).

\section{ERYTHRODERMA (EXFOLIATIVE DERMATITIS)}

The terms of erythroderma and exfoliative dermatitis are used synonymously in the literature for same entity, and they are different terminologies used for a common clinical presentation. Erythroderma is described as a persistent, severe, and generalized inflammation of the skin involving at least $90 \%$ of the body surface area (Figure 2). Early diagnosis and treatment of erythroderma decrease mortality and morbidity (28). The male to female ratio is $2: 1$, and it

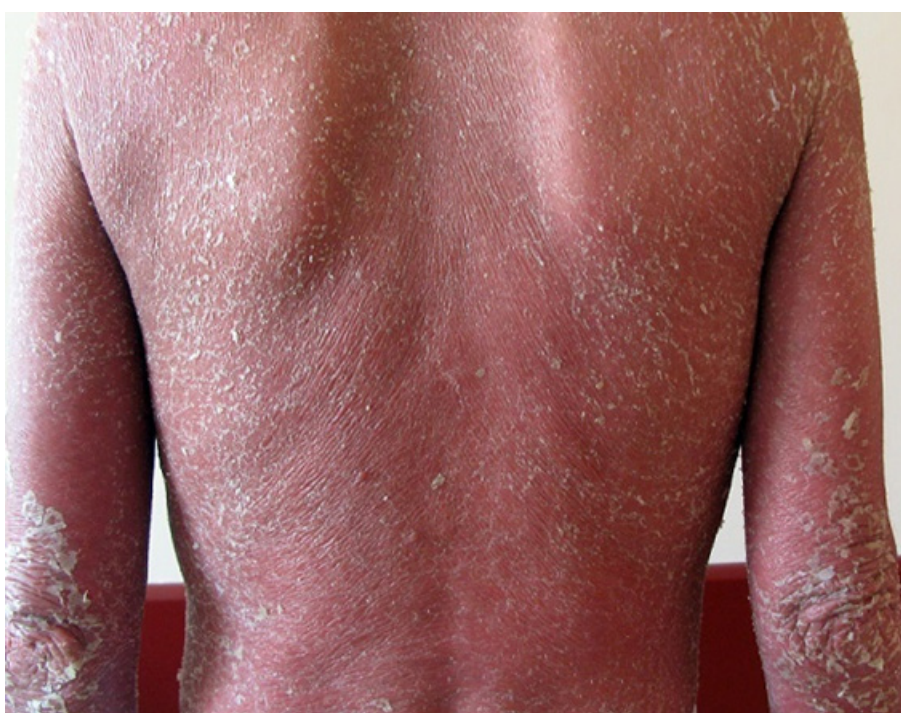

Figure 2. Erythroderma

is more commonly seen in adults aged over 40 years.

\section{Differential Diagnosis}

The clinical diagnosis of erythroderma is rather easy; however, it is not always possible to detect the underlying disease. In almost $30 \%$ of the cases, the etiology cannot be detected, and this condition is called idiopathic erythroderma. At the advanced stages of the disease, cases of idiopathic erythroderma have cutaneous $T$ cell lymphoma. These patients should be followed-up in terms of T-cell lymphoma by performing skin biopsies at intervals. Mucosal membranes are usually not affected; pretibial edema, periorbital edema, and ectropion might be seen (29). The most common symptom, other than the skin symptoms, is multiple lymphadenopathy (29). The most common cause of erythroderma is psoriasis in adults (28). In children, drug reactions are the most common cause of erythroderma, and psoriasis is the second most common. The causes of erythroderma can be summarized as SCALPID (29); Seborrheic Dermatitis/Sarcoidosis, Contact Dermatitis, Atopic Dermatitis, Lymphoma/Leukemia (Sezary syndrome), Psoriasis/Pityriasis Rubra Pilaris, Infections (HIV, Dermatophytosis), Drug reactions.

\section{Treatment}

The most important step is supportive care. Fluidelectrolyte balance should be regulated without overload, protein-rich diet should be provided, infections should be treated, thermoregulation should 
be controlled, and, if cardiovascular deficiency develops due to vasodilation in skin, it should be treated. The mortality rate is about $20 \%$. Acitretin, methotrexate, and cyclosporine are used for psoriatic erythroderma. Cyclosporine should be the first choice if there is no contraindication. Systemic steroids, azathioprine, interferon, infliximab, and IVIG can be used to treat erythroderma (29). Corticosteroid therapy should be administered carefully since it may cause rebound activation of pustular psoriasis on the surface by increasing fluid retention and hypokalemia (29).

\section{PEMPHIGUS VULGARIS}

Pemphigus is a chronic and fatal autoimmune bullous skin disorder that is associated with the loss of adhesion between the keratinocytes in skin and mucosa (30). It has four main clinical forms: pemphigus vulgaris, pemphigus foliaceus, paraneoplastic pemphigus, and IgA pemphigus. Pemphigus vulgaris $(\mathrm{PV})$ is the most common subtype of pemphigus, and, unless it is treated, it has no tendency to heal, and it has a progressive course that leads to death by means of expanding lesions on the mucosal surfaces and/or skin (Figure 3) (30). Almost all patients with PV develop painful erosions in the oral mucosa (31). The initial lesions appear on the oral mucosa in $80 \%$ of the patients. More than half of the patients also have cutaneous bullous and erosions. Therefore, oral lesions may be the only clinical indicator in certain

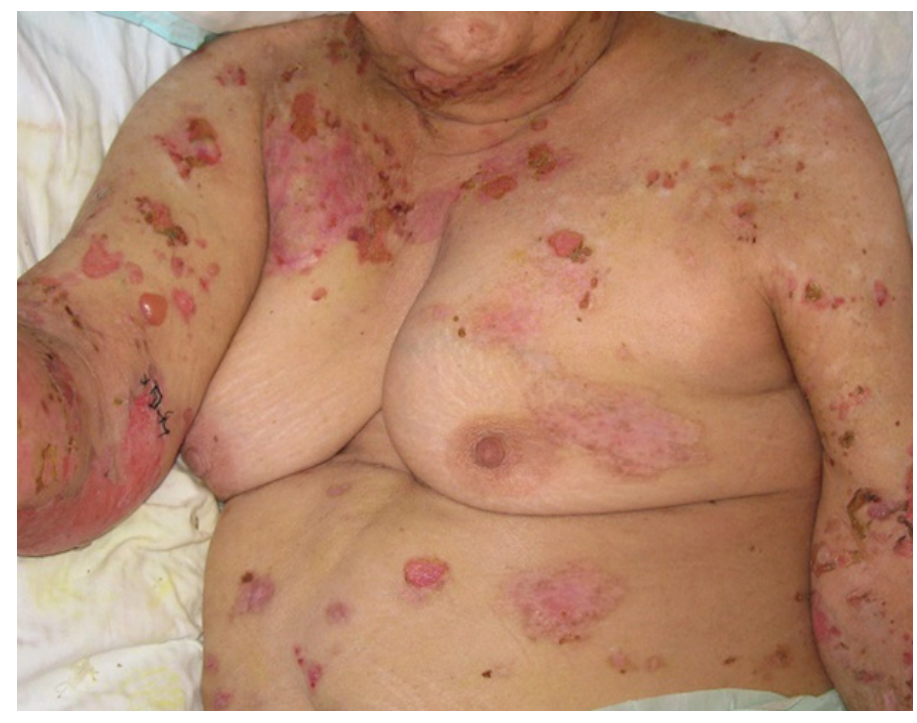

Figure 3. Bullous and erosive lesions with nikolsky positivity on the skin in pemphigus vulgaris patients. Lesion may develop on other mucosal membranes such as the conjunctiva, the larynx, the pharynx, the esophagus, the vulva, and the urethra (31).

\section{Differential Diagnosis}

The differential diagnosis should be performed with generalized bullous drug reactions and erythema multiforme. When the lesions are only on the oral mucosa, it may be confused with bullous pemphigoid, erosive lichen planus, cicatricial pemphigoid, erythema multiforme, hand-foot-mouth disease, Behcet's disease, necrotizing gingivostomatitis, recurrent aphthous stomatitis, acute herpetic stomatitis, oral fix drug reactions, and lupus erythematosus (30). The disease is diagnosed with clinical features and typical histopathological and immunofluorescence findings (antibodies that progress against the keratinocyte cell surface in the circulation and the skin) (30). Tzanck's cytodiagnostic test, which is based on the detection of acantholytic cells by examining the material scraped from the bulla surface under a microscope, has a significant role in the rapid diagnosis of pemphigus (32).

\section{Treatment}

Bulla and erosions spread through the surroundings and cause severe mortal infections and/or metabolic disorders in untreated patients (30). Before the use of systemic corticosteroids, almost three fourth of the patients were dead within a year (31). Recently, because of advanced diagnostic methods and therapy approaches, the mortality rate is reported as between $5 \%$ and $20 \%$ (32). The therapy regimen commonly involves the use of systemic corticosteroid with an immunosuppressive agent according to disease activity (32). Immunosuppressive agents that are used together with systemic corticosteroids are called adjuvant therapies (Table 5). Azatiopurine is the most common adjuvant therapy used in PV (33).

\section{GENERALIZED PUSTULAR PSORIASIS}

Generalized pustular psoriasis (GPP) is a rare variant of psoriasis that is characterized by abruptonset episodes with widespread pustular lesions and erythema over the whole body (Figure 4) (34). The face is not usually involved. The triggers for GPP involve pregnancy, sudden withdrawal of systemic corticosteroids, nonsteroidal anti-inflammatory drugs, hypocalcemia, infections, and topical irritants (34). The symptoms of high fever, general condition disorder, cachexia, elevated sedimentation rate, hypocalcemia, and leukocytosis are commonly seen in patients (35). A histopathological examination reveals spongiform 
Table 5. First-line and second-line adjuvant treatment agents

First-line Adjuvant Therapy
1. Azathioprine (1 to $3 \mathrm{mg} / \mathrm{kg} /$ day).
2. Mycophenolate mofetil, most effective
dose $25-35 \mathrm{mg} / \mathrm{kg} / \mathrm{day}$ (usually 1000 to
$1500 \mathrm{mg}$ administered orally twice a day;
however, if mycophenolic acid is used,
the daily dose is $1,440 \mathrm{mg}$ )

the daily dose is $1,440 \mathrm{mg}$ )
Second-line Adjuvant Therapy

1. Rituximab (anti-CD20 monoclonal antibody).

$2 \times 1 \mathrm{~g}$ IV (every two weeks) or $4 \times 375 \mathrm{mg} / \mathrm{m} 2$ (weekly)

2. IVIG (2 $\mathrm{g} / \mathrm{kg} / \mathrm{month})$

3. Immunoadsorption(consequent four days, 2 cycles, every four weeks)

4. Cyclophosphamide (500 mg IV bolus or orally $2 \mathrm{mg} / \mathrm{kg} / \mathrm{day}$ )

5. Methotrexate (10 to $20 \mathrm{mg} /$ week)

6. Dapsone $(100 \mathrm{mg} / \mathrm{day}$ or $\leq 1.5 \mathrm{mg} / \mathrm{kg} /$ day $)$

pustules on the upper layers of the epidermis and epidermal cells and polymorphonuclear leukocytes in the pustules (35).

\section{Differential Diagnosis}

The first disease that should be considered for a differential diagnosis of pustular psoriasis is acute generalized exanthematous pustulosis (AGEP). The pustules of psoriasis and AGEP cannot be clinically distinguished (35). Histopathologically, intraepidermal/ subcorneal pustules are observed in both diseases. However, the histopathological findings involving eosinophils, necrotic keratinocyte, the presence of interstitial-dermal perivascular infiltrate, and the

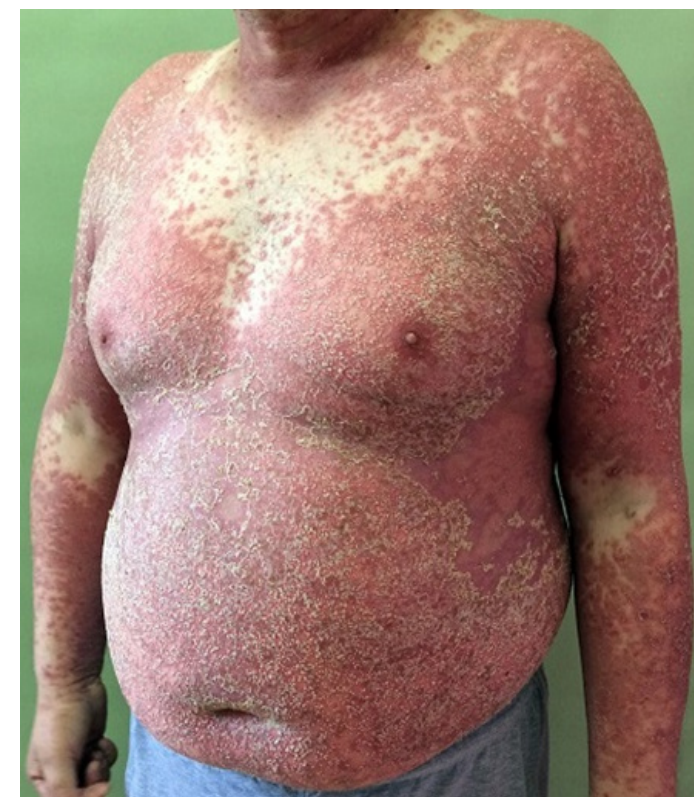

Figure 4. Widespread pustular lesions and erythema on whole body in pustular psoriasis absence of tortuous/dilated vessels are not present in pustular psoriasis. Moreover, pustular psoriasis is associated with papillomatosis and acanthosis in the dermis (35). Other diseases that should be considered for differential diagnosis are SneddonWilkinson disease, subcorneal IgA dermatosis, acnelike eruptions, and pustular contact dermatitis.

\section{Treatment}

Patients whose condition rapidly worsens should be hospitalized, metabolic loading should be prevented, electrolyte imbalance should be corrected, and attention should be paid to the sepsis that might be associated with staphylococcal and streptococcal superinfection. Cyclosporine, methotrexate, and acitretin can be used (34). Systemic steroids are not recommended in plaque-type psoriasis, but they can be used in pustular psoriasis in the short-term (35). Biological agents, such as infliximab and adalimumab, can be used for a rapid response (34).

\section{ACUTE GENERALIZED CONTACT DERMATITIS}

Contact eczemas are divided into two groups: allergic contact eczema and irritant contact eczema (36). Contact dermatitis is a type 4 hypersensitivity reaction and occurs after exposure of the skin to a contact allergen (36). Allergic contact dermatitis constitutes $20 \%$ of all contact dermatitis. Nickel is most common cause of allergic contact dermatitis (37).

\section{Differential Diagnosis}

Atopic dermatitis, nummular dermatitis, hypertrophic lichen planus, and lichen simplex chronicus may be considered in differential diagnosis (36). Histopathological examination can be used for a differential diagnosis. The skin patch test has been accepted as the gold standard for detecting the responsible antigens (37). 


\section{Treatment}

Systemic antihistamines and topical/systemic corticosteroids may be administered for treatment (36). In patients with contact dermatitis, the primacy is to detect and avoid the causative substance (38). If allergic contact dermatitis involves an extensive area of skin, systemic steroid therapy is often required and offers relief within 12 to 24 hours. Five to seven days of prednisone, 0.5 to $1 \mathrm{mg}$ per $\mathrm{kg}$ daily, is suggested (38). If the patient is comfortable after this first therapy, the dose may be reduced by 50 percent for the next five to seven days. The rate of reduction of the steroid dosage depends on factors such as the severity and duration of allergic contact dermatitis, and how effectively the allergen can be avoided. In severe dermatitis, oral prednisone should be tapered over two to three weeks because rapid discontinuation of steroids can cause rebound dermatitis (38).

\section{OTHER DERMATOLOGIC EMERGENCIES}

\section{Acute Generalized Exanthematous Pustulosis}

Acute generalized exanthematous pustulosis (AGEP) is a rare reaction pattern that is primarily induced by drugs and characterized by an abrupt onset of fever and generalized pustular lesions on the body (39). A wide range of drug groups has been strongly associated with AGEP (39). B-lactam antibiotics are one of most commonly used class, and the rest involve macrolides, tetracyclines, quinolones, aminoglycosides, sulfonamides, allopurinol, metronidazole, nystatin, isoniazid, furosemide, diltiazem, nonsteroidal anti-inflammatory drugs, codeine, dexamethasone, carbamazepine, and phenytoin (39).

\section{Differential Diagnosis}

The diseases that should be considered for the differential diagnosis are pustular psoriasis, SneddonWilkinson disease, and subcorneal IgA dermatosis. The significance of the tests, including in vivo (skin patch test), in vitro (lymphocyte transformation test and cytokine release test), and both in vivo and in vitro has been shown to detect the drugs that cause AGEP.

\section{Treatment}

The elimination of the underlying disease provides a spontaneous recovery within weeks in most of the patients. Systemic antihistamines, topical moisturizer lotions, and ointments containing corticosteroids are adequate in mild cases (39). Systemic corticosteroids are recommended for large lesions. There are case reports that indicate that etanercept, infliximab, and cyclosporine are effective in certain cases resistant to systemic steroids (40).

\section{Drug Reaction with Eosinophilia and Systemic Symptoms (DRESS) Syndrome}

DRESS is a life-threatening, quite rare, acute, and idiosyncratic drug reaction (41). The spectrum of skin symptoms is rather wide. When the disease clinic has been completely developed, severe mucocutaneous rash and fever, lymphadenopathy, hematological disorders, and internal organ involvement might be seen (42). The most affected internal organ is the liver in DRESS syndrome (70\%).

\section{Differential Diagnosis}

DRESS syndrome does not have a specific clinical and laboratory finding (43). The diagnosis of DRESS syndrome might be challenging due to the variability of organ involvement and skin symptoms (41). It starts within 1-8 weeks after taking the drug. Other drug reactions, leukemia, lymphoma, and hypereosinophilic syndrome should be considered for a differential diagnosis (41).

\section{Treatment}

DRESS syndrome is a life-threatening condition with a mortality rate of about $10-20 \%$ (42). Mortality is usually associated with liver involvement and secondary bacterial infections. It can be successfully treated by topical/systemic steroids, antihistamines, IVIG, and cyclosporine (41). Although it is contradictory, the addition of $\mathrm{N}$-acetyl-cysteine to the treatment is believed to prevent the progression of liver damage (43).

\section{Acute graft versus host disease}

Acute graft versus host disease (GvHD) has been accepted as the most significant cause of mortality and morbidity after allogeneic bone marrow transplant (44). The first signs of acute GvHD are usually skin symptoms. There is a maculopapular rash which is indistinguishable from the morbilliform drug reaction when the patient is admitted to the emergency department (44). Epidermal necrosis and bullous lesions occur in severe acute GvHD.

\section{Differential Diagnosis}

Drug toxicity, especially antibiotics, and the side effects of the priming regimen must be kept in mind in case of the presence of an erythematous rash in stem cell transplant patients. Skin biopsy is important for early diagnosis (45). Erythematous rash, hepatitis characterized by icterus, and gastroenteritis (stomach pain and diarrhea) are accepted as the clinical triad for acute GvHD (44).

\section{Treatment}


The treatment of acute GvHD is among the most significant problems in stem cell transplantation centers (46). Corticosteroids, cyclosporine, methotrexate, and antithymocyte-globulin (ATG) can be used in the treatment of acute GvHD (45).

\section{CONCLUSION}

It is not appropriate to apply a symptomatic treatment approach without a clear diagnosis; firstly, the diagnosis should be clarified, and then, the treatment should be initiated (1). The use of systemic corticosteroid drugs without a clear diagnosis may affect the diagnostic accuracy of biopsy and direct immunofluorescence (DIF), promotes psoriasis vulgaris to pustular or erythrodermic form, and exacerbates viral-bacterial conditions (2). Attention should be paid to conditions involving hypovolemia, fluid-electrolyte disorder, concomitant infection, and hypoalbuminemia; and the patient should be evaluated with a multidisciplinary and integrated approach (3). Dermatologic emergencies usually require intensive care interventions (4). Therefore, they should be evaluated as multidisciplinary in tertiary healthcare services (5). Emergency medicine specialists should increase their knowledge of dermatologic emergencies (5). In this article, we listed dermatologic emergencies that are encountered by both dermatologists and non-dermatology specialist physicians under the subtitles of etiopathogenesis, clinics, diagnosis, and treatment.

We believe that this review article would be particularly helpful to dermatologists, emergency medicine specialists, primary care physicians, and all physicians providing emergency health services because of the high prevalence and importance of dermatologic emergencies and the limited data available on this issue in the literature.

Conflict of interest: Authors declare that there is no conflict of interest between the authors of the article.

Financial conflict of interest: Authors declare that they did not receive any financial support in this study.

Address correspondence to: Selami Aykut Temiz, Necmettin Erbakan University, Meram Faculty of Medicine, Department of Dermatology, Konya, Turkey

Phone: +05358430068

e-mail: aykutmd42@gmail.com

\section{REFERENCES}

1. Browne BJ, Edwards B, Rogers RL. Dermatologic emergencies. Prim Care 2006;33:685-95.
2. Unal G. Dermatological emergencies. Cerrahpaşa J Med 2002;33:132-7.

3. Hamilton GC, Sanders AB, Strange GR, et al. Emergency medicine: An approach to clinical problem-solving, 2nd ed. Philadelphia, PA: Saunders;2003:185-206.

4. Erdogan HK, Altunay IK, Koslu A. Evaluation of dermatologic emergency patients: An unicentral prospective clinical study. Archives of the Turkish Dermatology and Venerology 2009;144-9.

5. Bancalari-Díaz D, Gimeno-Mateos LI, Cañueto J, et al. Estudio descriptivo de urgencias dermatológicas en un hospital terciario. Actas dermosifiliogr 2016;107(8),666-73.

6. Sabroe RA. Acute urticaria. Immunol Allergy Clin North Am 2014;34(1):11-21.

7. Zuberbier T, Aberer W, Asero R, et al. The EAACI/GA2LEN/ EDF/WAO guideline for the definition, classification, diagnosis, and management of urticaria: The 2013 revision and update. Allergy 2014;69(7),868-87.

8. Aktaş $\mathrm{H}$, Ergin C. A severe hereditary angioedema attack rapidly improved with fresh frozen plasma. Selcuk Med J 2016;32(Ek Sayı):45-6

9. Powell RJ, Leech SC, Till S, et al. BSACl guideline for the management of chronic urticaria and angioedema. Clin Exp Allergy 2015;45(3),547-65.

10. Ben-Shoshan M, Clarke AE. Anaphylaxis: Past, present and future. Allergy 2011;66(1),1-14.

11. Muraro A, Roberts G, Worm M, et al. Anaphylaxis: Guidelines from the European academy of allergy and clinical immunology. Allergy 2014;69(8),1026-45.

12. Paulmann M, Mockenhaupt $M$. Severe drug-induced skin reactions: Clinical features, diagnosis, etiology, and therapy. JDDG: J Dtsch Dermatol Ges 2015;13(7),625-43.

13. Mckenhaupt M. The current understanding of stevensjohnson syndrome and toxic epidermal necrolysis. Expert Rev Clin Immunol 2011;7(6):803-13.

14. Dao RL, Su SC, Chung WH. Recent advances of pharmacogenomics in severe cutaneous adverse reactions: Immune and nonimmune mechanisms. Asia Pac Allergy 2015;5(2),59.

15. Valeyrie-Allanore L, Ingen-Housz-Oro S, Chosidow O, et al. French referral center management of Stevens-Johnson syndrome/toxic epidermal necrolysis. Dermatologica Sinica 2013;31(4),191-5

16. Schneck J, Fagot JP, Sekula P, et al. Effects of treatments on the mortality of Stevens-Johnson syndrome and toxic epidermal necrolysis: A retrospective study on patients included in the prospective EuroSCAR study. J Am Acad Dermatol 2008;58:33-40.

17. Bachot N, Revuz J, Roujeau J. Intravenous immunoglobulin treatment for Stevens-Johnson syndrome and toxic epidermal necrolysis a prospective noncomparative study showing no benefit on mortality or progression. Arch Dermatol 2003:139(1):33-6.

18. Aykut TS, Recep D, Munise D, et al. A Case of bupropioninduced toxic epidermal necrolysis (TEN). Ann Clin Case Rep 2017;2,1396.

19. Handler MZ, Schwartz RA. Staphylococcal scalded skin syndrome: Diagnosis and management in children and adults. J Eur Acad Dermatol Venereol 2014;28(11),1418-23.

20. Martin SM, Shoham SC, Alsup M, et al. Genetic mapping in phage group 2 staphylococcus aureus. Infect Immun $1980 ; 27(2), 532-41$. 
21. Hennigan K, Riley C. Staphylococcal scalded skin syndrome: A case review. Neonatal Netw 2016;35(1),8-12.

22. Blyth M, Estela C, Young AE. Severe staphylococcal scalded skin syndrome in children. Burns 2008;34(1),98-103.

23. Temiz SA, Özer İ, Ataseven A, et al. A Case of staphylococcal scalded skin syndrome in a 1-year old boy with otitis media. J Emerg Med Case Rep 2018;9(4):71-4.

24. LeRiche T, Black AY, Fleming NA. Toxic shock syndrome of a probable gynecologic source in an adolescent: $A$ case report and review of the literature. J Pediatr Adolesc Gynecol 2012;25(6),e133-7.

25. Al-ajmi JA, Hill P, O' Boyle C, et al. Group a streptococcus toxic shock syndrome: An outbreak report and review of the literature. J Infect Public Health 2012;5:388-93.

26. Halpern AV, Heymann WR. Bacterial diseases. In: Bolognia JL, Jorizzo JL, Rapini RP, editors. Dermatology, vol. 1. 2nd ed. St. Louis: Mosby; 2008.p.1075-106.

27. Lappin E, Ferguson AJ. Gram-positive toxic shock syndromes. Lancet Infect Dis 2009;9(5),281-90.

28. Thomson MA, Berth-Jones J. Erythroderma and exfoliative dermatitis. In life-threatening dermatoses and emergencies in dermatology 2009;79.

29. Mistry N, Gupta A, Alavi A, et al. A review of the diagnosis and management of erythroderma (generalized red skin). Adv Skin Wound Care 2015;28(5),228-36.

30. Venugopal SS, Murrell DF. Diagnosis and clinical features of pemphigus vulgaris. Immunol Allergy Clin North Am 2012;32:233-43.

31. Uzun S, Durdu $M$, Akman $A$, et al. Pemphigus in the mediterranean region of Turkey: A study of 148 cases. Int J Dermatol 2006;45:523-8.

32. Stanley JR. Pemphigus. In: Freedberg IM, Eisen AZ, Wolff K, et al. Fitzpatrick's dermatology in general medicine. 6th Ed, New York: McGraw-Hill Company 2003:558-67.

33. Chams-Davatchi C, Mortazavizadeh A, Daneshpazhooh M, et al. Randomized double blind trial of prednisolone and azathioprine, vs. prednisolone and placebo, in the treatment of pemphigus vulgaris. Journal of the European Academy of Dermatology and Venereology 2013;27(10),1285-92.
34. Gudjonsson JE, Elder JT. Psoriasis. In: Wolff K, Goldsmith LA, Katz SI, et al. eds. Fitzpatrick's dermatology in general medicine. New York: McGraw Hill 2008;169-93.

35. Braun-Falco O, Plewing G, Wolff HH, et al. Pustular diseases. Dermatology. 2. edition. Berlin: Springer-Verlag 2000;698708.

36. Mose M, Sommerlund M, Koppelhus U. Severe acute irritant contact dermatitis presenting as exfoliative erythroderma. Contact Dermatitis 2013;69:119-21.

37. Dogan S. Severe contact dermatitis due to camomile: A common complementary remedy with potential sensitization risks. Allergy Asthma Clin Immunol 2013;9:26.

38. Usatine RP, Riojas M. Diagnosis and management of contact dermatitis. Am Fam Physician 2010;82(3),249-55.

39. Momin SB, Del Rosso JQ, Michaels B, et al. Acute generalized exanthematous pustulosis: An enigmatic druginduced reaction. Cutis 2009;83:291.

40. Diaz L, Ciurea AM. Cutaneous and systemic adverse reactions to antibiotics. Dermatol Ther 2012;25:12-22.

41. Cacoub P, Musette $P$, Descamps V, et al. The DRESS syndrome: A literature review. Am J Med 2011;124:588-97.

42. Criado PR, Criado RFJ, Avancini JM, et al: Drug reaction with eosinophilia and systemic symptoms (DRESS)/ druginduced hypersensitivity syndrome (DIHS): A review of current concepts. An Bras Dermatol 2012;87:435-49.

43. Moling O, Tappeiner L, Piccin A, et al. Treatment of DIHS/ DRESS syndrome with combined $\mathrm{N}$-acetylcysteine, prednisone and valganciclovir-a hypothesis. Med Sci Monit 2012;18:57-62.

44. Teshima T, Ferrara JLM. Understanding the alloresponse: New approaches to graft-versus-host disease prevention. Semin Hematol 2002;39:15-22.

45. Sullivan KM. Graft-versus-host disease. In: Blume KG and Forman SJ, Appelbaum FR, eds. Thomas's hematopoietic cell transplantation. 3rd edition Boston: Blackwell Scientific Publishers, 2004;p.635-64.

46. Häusermann $P$, Walter RB, Halter $J$, et al. Cutaneous graft versus-host disease: A guide for the dermatologist. Dermatology 2008;216:287-304. 